\title{
GARANTISMO, SISTEMA ACUSATÓRIO E A PRODUÇÃO DE PROVA EX OFFICIO PELO MAGISTRADO
}

\section{GUARANTEE, ADVERSARIAL SYSTEM AND PRODUCTION OF EX OFFICIO EVIDENCE BY THE JUDGE}

\section{TEODORO SILVA SANTOS}

Desembargador do Tribunal de Justiça do Ceará, atual Corregedor-Geral da Justiça do Ceará (Biênio 2019/2021). Email: profteodoro@ig.com.br. Bacharel em Ciências Jurídicas (UNIFOR). Especialista em Direito Processual Penal (UFC) e Direito Constitucional (UNIFOR), Mestre em Direito Constitucional (UNIFOR), Doutorando em Direito Constitucional (UNIFOR).

\section{NESTOR EDUARDO ARARUNA SANTIAGO}

Mestre e Especialista em Direito pela Universidade Federal de Minas Gerais, com estágio Pós-doutoral pela Universidade do Minho. Professor Titular do Programa de Pós-Graduação Stricto Sensu e do Curso de Graduação em Direito da Universidade de Fortaleza. Professor do Curso de Graduação em Direito da Universidade Federal do Ceará. Advogado criminalista. E-mail: nestorsantiago@unifor.br

\section{RESUMO}

Objetivo: A análise da possibilidade de produção de provas ex officio pelo magistrado, prevista na redação do inciso I do art. 156 do Código de Processo Penal, advinda da reforma implementada pela Lei no. 11.690/2008, que alterou os dispositivos relativos à prova no Processo Penal à luz da Constituição e do Garantismo Penal.

Metodologia: Métodos analítico e dedutivo, mediante pesquisa bibliográfica e documental de doutrina e jurisprudência, especialmente dos tribunais superiores 
brasileiros e do Tribunal Europeu de Direitos Humanos, no âmbito do modelo garantista constitucional e também legal.

Resultados: A possibilidade de iniciativa probatória pelo juiz no processo penal antes de iniciada a ação penal, expressa no art. 156, inciso I, do Código de Processo Penal, com a redação advinda da Lei №. 11.690/2008, contrapõe-se ao garantismo penal, bem como à Constituição, por colocar em risco a imparcialidade judicial. A norma se exprime como resquício de um regime inquisitorial, por afrontar os direitos e as garantias fundamentais, notadamente o princípio da imparcialidade, alcançado por meio do distanciamento do magistrado da função probatória.

Contribuições: $O$ tema é relevante, pois abre espaço para uma análise precisa da persecução da verdade no contexto do processo penal ante a possibilidade de atuação ex officio do juiz na produção de provas, fato este que se contrapõe ao sistema processual acusatório adotado no Brasil, centrado na existência de sujeitos processuais diversos e detentores de funções distintas: acusar, defender e julgar, em consonância com o princípio do devido processo legal e de outros princípios corolários deste.

Palavras-chave: sistema acusatório; garantismo processual; produção de prova ex officio; imparcialidade.

\section{ABSTRACT}

Objective: To analyze the possibility of producing ex officio evidence by the magistrate, provided for in item I of article 156 of the Code of Criminal Procedure, arising from the reform implemented by Law no. 11,690/2008, which amended the provisions relating to evidence in the Criminal Procedure in the light of the Constitution and the Penal Guarantee.

Methodology: Analytic and deductive methods, by way of bibliographic and documentary research of doctrine and jurisprudence, especially from the Brazilian higher courts and the European Court of Human Rights, within the scope of the constitutional and also legal guarantee model.

Results: The possibility of evidential initiative by the judge in the criminal process before the beginning of the criminal lawsuit, expressed in Article 156, item I of the Criminal Procedure Code, with the wording granted by Law no. 11,690/2008, opposes the criminal guarantee, as well as the Constitution, for putting at risk the judicial impartiality. The law expresses as a remnant of an inquisitorial regime to affront fundamental rights and guarantees, notably the principle of impartiality, achieved by way of distancing the magistrate from the evidence function. 
Contributions: The topic is relevant, as it opens up an accurate analysis of the pursuit of the truth in the context of criminal proceedings given the possibility of ex officio action by the judge in the production of evidence, a fact that contrasts with the accusatory procedural system adopted in Brazil, centered in the existence of different procedural subjects and holders of different functions: accusing, defending and judging, in line with the principle of due legal process and other corollary principles thereof.

Keywords: accusatory system; procedural guarantee; production of ex officio evidence; impartiality.

\section{INTRODUÇÃO}

Efetiva-se uma abordagem, em especificidade, acerca da produção da prova no processo penal ex offício pelo juiz, conforme preconiza o inciso I do artigo 156 do Código de Processo Penal, com a redação da Lei no. 11.690, de 9 de junho de 2008, que alterou os dispositivos relativos à prova, sobre as perspectivas do sistema acusatório e da teoria do garantismo aplicada ao processo penal.

O garantismo, quando encarado como teoria do direito, não pode ser relegado à simples defesa do legalismo normativista: baseia-se na dignidade da pessoa e na tutela dos direitos fundamentais delineados na Constituição, visando a alcançar os fins preconizados pelo Estado Democrático de Direito.

Neste sentido, à medida que o Poder Judiciário supervaloriza sua atuação, desempenhando, muitas vezes, as funções de outros poderes, ainda que seja para a realização dos fins estabelecidos na Constituição Federal, ou, ainda, provindo das decisões judiciais advindas de uma ampla discricionariedade, dá oportunidade a que se instale verdadeiro conflito, podendo este levar ao desequilíbrio e à instabilidade da ordem constitucional.

Trazendo para a óptica do processo penal, o Garantismo Penal, defendido por Ferrajoli (2002), possibilita a realização do Direito Penal, para que, de um lado, existam o processamento do feito e a viabilidade de aplicação da pena, bem como seja efetivada, no âmbito do processo, a garantia dos direitos e das liberdades 
individuais do sujeito (LOPES JR, 2005), limitando a atuação do Estado para garantir a eficácia dos direitos fundamentais do acusado, base do ideal garantista.

Veja-se que a Constituição tratou dos direitos e garantias fundamentais, firmando sua efetivação que, por meio do Direito Processual, pelo próprio princípio da inafastabilidade da jurisdição (art. 5ํ., inc. XXXV), convocará o magistrado a assumir atitude garante daqueles direitos e garantias, encarando a legitimidade de sua atuação como constitucional e não política.

Com efeito, faz-se necessário discorrer sobre o garantismo em sua vertente penal e os sistemas processuais penais, inquisitório e acusatório, para alcançar-se o debate acerca da nova redação do inciso I do artigo 156 do Código de Processo Penal, que passou a permitir a produção de prova de ofício pelo magistrado.

O tema é relevante, abrindo espaço para uma análise acurada da persecução da verdade no contexto do processo penal, ante a possibilidade de atuação ex officio do juiz na produção de provas, fato este que se contrapõe ao sistema processual acusatório adotado no Brasil, centrado na existência de sujeitos processuais diversos e detentores de funções distintas: acusar, defender e julgar, em consonância com o princípio do devido processo legal e outros princípios corolários deste. Assim, a investigação em relevo visa a interpretar a redação do dispositivo, de modo a adequá-lo a um sistema processual penal em sintonia com o modelo garantista.

As fontes primárias deste estudo consistem na Constituição, no Código de Processo Penal e no Projeto do Novo Código de Processo Penal, já aprovado pelo Senado Federal (Projeto de Lei ‥ 156/09), em trâmite na Câmara (PL ํo. 8.045/2010).

A metodologia aplicada neste ensaio é de cunho bibliográfico, executada por meio de pesquisas doutrinária e jurisprudencial, especialmente dos tribunais superiores brasileiros e do Tribunal Europeu de Direitos Humanos (TEDH), no âmbito do modelo garantista, constitucional e também legal, notadamente quanto à iniciativa probatória pelo magistrado. A pesquisa desenvolveu-se mediante a busca 
de resultado, na modalidade pura, com o fim único de ampliação dos conhecimentos.

Ademais, quanto aos métodos de abordagem, foram utilizados, em especial, os analíticos e os dedutivos, haja vista estes últimos permitirem que se parta do geral (postulados constitucionais de índole processual penal), rumo ao método específico (poder instrutório do magistrado à vista desses postulados), ressaltandose que o primeiro método é considerado imprescindível para a realização de estudo amplo e profundo dos aspectos jurídicos inerentes ao tema. Quanto aos fins, a pesquisa se dá nas modalidades descritiva e exploratória, pretendendo descrever a matéria abordada, demandando elevar o modo como esta é enfrentada.

O experimento sob relação expressa, na primeira parte, apresenta breve explanação acerca dos sistemas processuais penais, procedendo a uma análise dos sistemas inquisitivo e acusatório à luz do Constitucionalismo Garantista, na busca de uma compatibilização com o Estado Democrático de Direito.

Em sequência, analisa-se a chamada Reforma do Direito Processual Penal, de 2008, ocasionada com a publicação de um conjunto de leis que alteraram o CPP, notadamente a Lei n. 11.690/2008, modificadora do inciso I do artigo 156, prevendo a possibilidade de produção de prova ex officio pelo magistrado, antes mesmo de iniciada a ação penal. Ainda no segundo módulo, procedeu-se à análise da iniciativa probatória do magistrado, confrontando-se ao modelo garantista e devido processo constitucional, bem assim dos princípios deste último decorrentes.

No capítulo terceiro, procede-se a uma análise da garantia da imparcialidade do magistrado, prevista na CF, contrapondo-se à previsão de iniciativa de produção de prova ex officio pelo juiz, antevistana legislação infraconstitucional.

Por fim, demonstra-se que a possibilidade de iniciativa probatória pelo juiz no processo penal, antes de iniciada a ação penal propriamente dita, expressa no artigo 156, I do CPP, redação advinda da Lei n. 11.690/2008, contrapõe-se ao garantismo penal, bem como à própria $\mathrm{CF}$, porque põe em risco a imparcialidade judicial. 


\section{OS SISTEMAS PROCESSUAIS PENAIS À LUZ DO CONSTITUCIONALISMO GARANTISTA}

Os sistemas processuais classificam-se em inquisitório e acusatório. $\mathrm{O}$ sistema inquisitório, de maneira sucinta, refere-se à concentração, numa mesma pessoa, das três funções do processo penal (acusar, defender e julgar) (PRADO, 2005, p.149), centralizando tais atribuições num mesmo sujeito, sobressaindo a adoção deste sistema, especialmente, na Idade Média.

O sistema inquisitório adotado pelo Código de Processo Penal brasileiro de 1941 é de inspiração visivelmente fascista, cuja exposição de motivos preconizava a escolha de um sistema penal excepcionalmente repressivo e inibidor de garantias, enaltecendo a superioridade do Estado perante a pessoa, influenciado pelo Código de Processo Penal italiano de 1930, denominado Código Rocco.

Por outro lado, no sistema acusatório, as funções de acusar, defender e julgar são distribuídas a distintas pessoas, considerando, ainda, que o julgador não poderia acumular a função de julgar e investigar (FISCHER, 2011). Aqui, é possível verificar um distanciamento do julgador em relação ao objeto e às partes do processo, funcionando aquele como figura imparcial, que apenas deve ater-se à função de julgar, não produzindo prova nem defendendo qualquer das partes.

Além da divisão de funções dentro do processo, os sistemas processuais inquisitivo e acusatório divergem, também, em relação a quem incumbe a gestão da prova; no sistema acusatório, por adotar verdadeira desconcentração das atividades processuais, segregando objetivamente as funções de cada parte, o ônus probatório resta às partes - acusação e defesa - a iniciativa da produção de provas, não podendo transmutar-se tal incumbência à figura do julgador (WOTTRICH, 2010, p.123-136).

Discute-se se o sistema processual penal adotado no País conforma-se como misto ou acusatório. Parte da doutrina entende ser misto o sistema de persecução penal, apontando que este se divide, em fase primária, num sistema inquisitivo, assegurada a discricionariedade da autoridade policial condutora do 
procedimento de inquérito (fase pré-processual), seguindo para a segunda fase que, norteada pelo modelo acusatório, arrima-se na manifestação das partes processuais, detentoras de funções previamente delimitadas (BARROS, 2012, p.145). Malgrado a dificuldade de dissociar-se os sistemas processuais penais, isolando-os em seu formato puro, entende-se que, na verdade, deve-se partir do princípio informador de cada sistema reconhecido, para que se alcance o sistema norteador do processualismo.

Lopes Junior (2007, p. 24) leciona: "[...] ainda que todos os sistemas sejam mistos, não existe um princípio fundamentalmente misto. O misto deve ser visto como algo que, ainda que mesclado, na essência é inquisitório ou acusatório." Logo, tem de ser analisado qual princípio estrutura o sistema adotado, princípio dispositivo, o qual funda o sistema acusatório, ou, princípio inquisitivo, fundador de um sistema inquisitório.

A identificação do princípio informador de uma conjuntura processual serviria para apontar o sistema processual penal adotado, sendo este determinante para nortear a atuação dos sujeitos processuais. Assim, entende-se que o sistema misto padece de um núcleo fundante próprio. Ademais, não haveria como se entender aquele como uma miscelânea dos princípios informadores dos sistemas inquisitivo e acusatório, considerando que estes figuram em lados opostos.

Logo, ao cogitar-se na existência de características de um sistema inquisitivo, tal já permitiria que a legislação infraconstitucional detivesse inclinações anti-garantistas, pois, a rigor, os elementos inquisitórios são incompatíveis em relação a um sistema dotado de princípios e normas definidoras de direitos e garantias fundamentais - evidenciando um sistema acusatório - ao passo que aqueles norteariam um modelo repressivo e autoritário, contrário aos ditames do Estado Democrático de Direito e da Teoria do Garantismo.

A teoria garantista oferecida por Ferrajoli (2002), entendida como modelo de Direito, baseia-se na obediência à dignidade da pessoa humana, bem como nos direitos fundamentais, sujeitando-se às máximas constitucionalmente previstas, porquanto, num Estado Democrático de Direito, deve-se preconizar o alcance ao 
sentido material da democracia, garantindo-se a efetivação dos direitos constitucionais, sob pena de deslegitimar-se as instituições estatais (ROSA, 2003, p.20). Nesta lógica, Miranda (2005, p.199-219) defende que somente há direitos fundamentais quando o Estado e a pessoa, a autoridade e a liberdade distinguem-se e, até, em maior ou menor medida, contrapõem-se.

Destarte, o Garantismo Jurídico centra-se, justamente, na busca da efetivação dos direitos fundamentais, bem como na própria proteção da pessoa dos arbítrios estatais, ao recobrar o princípio da legalidade com o desiderato de restringir os espaços/limites concedidos à discricionariedade do juiz para que aquela seja mais democrática e menos pessoal, ou seja, exige-se a interpretação (e aplicação) das normas em plena sintonia com a Constituição.

A teoria embasada por Ferrajoli defende, pois, a oposição entre a legalidade e o arbítrio, preconizando o recobro da estrita legalidade, com vistas a equilibrar o funcionamento democrático do sistema e a impedir que a atuação isolada e ativa do Judiciário venha a comprometer o Estado Democrático de Direito.

Visando à consecução de um verdadeiro Estado Democrático de Direito, com a efetiva implementação dos direitos e garantias fundamentais, tal como a Constituição alvitra, a Teoria do Garantismo, no que tange ao âmbito penal, incentiva um processo penal garantista, pois, baseando-se na obra de Ferrajoli, apenas um processo penal garantidor dos direitos do imputado e, consequentemente, limitador da discricionariedade do magistrado, pode conceder independência ao juiz e ao seu papel de controle da legalidade do poder (LOPES JR, 2005, p.24).

Ferrajoli (2001, p.38) ensina que os direitos fundamentais positivados nas constituições representam um sistema normativo limitante e ordenador do poder e atuação estatal, não se tratando de direitos "para o Estado" ou no interesse deste, mas sim, caso seja necessário, normativo "contra o Estado", entendendo esta expressão última como direitos a serem opostos às autoridades públicas, pelos quais estas terão de assentar suas ações. 
O modelo garantista influencia a seara penal, preocupando-se com a concretização dos direitos e garantias expressos na Constituição e nas leis infraconstitucionais. Percebe-se, com efeito, que a adoção de um sistema de processo acusatório coaduna-se, de pronto, com o modelo de Constituição garantista, que, por sua vez, compatibiliza-se com o Estado Democrático de Direito.

Importa consignar a ideia de que o garantismo não finda num mero legalismo ou num formalismo engessado. Para que se possa efetivar a tutela dos direitos fundamentais, é preciso que o magistrado encare o sistema normativo de maneira substancial, com o escopo de alcançar os fins valorativos deste, porquanto é o principal responsável quando da atividade jurisdicional.

É importante mencionar, entretanto, que, não obstante encarar-se o processo penal como instrumento para garantia dos direitos e liberdades individuais, o garantismo penal não busca "[...] abolir a pena ou deixar os culpados impunes, tendo como objetivo o respeito à dignidade da pessoa humana, racionalizando a punição estatal" (SABOIA; SANTIAGO, 2018).

Neste sentido, Ingo Sarlet (2015), leciona sobre eficácia dos direitos fundamentais: "[...] a dignidade da pessoa humana é simultaneamente limite e tarefa dos poderes estatais. Na condição de limite da atividade dos poderes públicos, a dignidade necessariamente é algo que pertence a cada um e que não pode ser perdido ou alienado".

A ordem constitucional vigente concentrou direitos e garantias, em sua maioria, no artigo 5‥ Em relação ao Direito Processual Penal, deve-se buscar a efetivação das garantias, destacando-se, a título de exemplo, a imparcialidade do magistrado, a presunção de inocência, o direito ao contraditório e à ampla defesa, além do devido processo legal.

Veja-se que, no processo penal, tendo em vista a persecução penal e o abalo que esta carreia às liberdades do perseguido, demanda-se assegurar efetivamente os direitos fundamentais. Assim, num Estado de Direito, há que se compatibilizar os direitos individuais e os meios coercitivos a serem utilizados pelos agentes estatais durante o encalço penal (PRADO, 2014, p. 16). 
É cediço o fato de que, embora a Constituição não contenha em seu texto expressamente consignada a adoção ao sistema acusatório, ao observar-se a implementação de um Estado Democrático de Direito, rompendo um ideal totalitário, para que sejam previstos direitos e garantias fundamentais, limitando a atuação do Estado como ente punidor, conclui-se que a ordem constitucional é regida por um sistema processual diverso do inquisitorial, sendo este próprio de um Estado autoritário.

Ao analisar-se a Constituição, vê-se que o sistema acusatório pode ser extraído desde a concepção máxima da dignidade da pessoa humana até o dever de implementar-se um devido processo legal, ante a figura de um juiz imparcial, o qual presidirá um procedimento, tendo sua função delimitada pelo próprio Texto Constitucional, não devendo ele se imiscuir nas funções outrora delineadas para o Ministério Público (função de acusar), bem como o mister investigativo que inaugura a fase pré-processual destinada às polícias.

Há, portanto, verdadeira contradição da Constituição, que se exprime sob o fundamento liberal e acusatório, relativamente à legislação infraconstitucional, precisamente o Código de Processo Penal, pelo qual é patente o fundamento no autoritarismo e num ideal antidemocrático, o que permite previsões legais que se aproximam de um modelo inquisitivo, fruto do fascismo italiano, subitamente afastando-se do processo acusatório e do garantismo penal.

Perante tal celeuma, importa mencionar, inclusive, a tramitação do Projeto do Novo Código de Processo Penal, já aprovado pelo Senado Federal (Projeto de Lei №. 156/09), em trâmite na Câmara (PL №. 8.045/2010), bem como as propostas de emendas já elaboradas, as quais foram analisadas pelo Comitê especial instituído para tal incumbência. ${ }^{1}$

Há uma proposta de emenda ao Projeto que exprime mudança substancial para o tema aqui tratado: a previsão expressa de adoção do processo penal acusatório a teor do artigo 4ํ․ do Projeto do Novo Código de Processo Penal. A

1 Comitê de análise do projeto do novo CPP. Comissão de acompanhamento legislativo e prerrogativas institucionais. CNPG. ANÁLISE do PROJETO DE LEI 156/2009do Senado (PL 8045/2010 na Câmara), que institui o Novo CÓDIGO DE PROCESSO PENAL. 20 de jul. 2011. 
redação do artigo 4‥ seria "[...] o processo penal terá estrutura acusatória, nos limites definidos neste Código, vedada a iniciativa do juiz na fase da investigação". Tal proposta almeja preencher uma lacuna na legislação penal do País, adotando expressamente o sistema acusatório como modelo norteador do processo penal.

\section{A INICIATIVA PROBATÓRIA DO JUIZ NA FASE PRÉ- PROCESSUAL, COM BASE NO INCISO I DO ARTIGO 156 DO CÓDIGO DE PROCESSO PENAL, SOB A ÓPTICA CONSTITUCIONAL E O MODELO GARANTISTA}

Antes do advento da Lei №. 11.690, de 9 de junho de 2008, o artigo 156 do Código de Processo Penal previa que, no concernente à atuação do magistrado, no curso da instrução processual ou antes de proferir sentença, poderia este determinar, de ofício, diligências com vistas a dirimir dúvidas sobre ponto relevante.

Mencionada lei alterou o dispositivo em comento, acrescentando dois incisos. O caput do artigo, bem como o inciso II, ao que parece, cuidaram de proceder a uma mera reprodução da redação anterior. In hoc sensu, o inciso I do mesmo artigo trouxe nova possibilidade: "o magistrado, antes mesmo de iniciada a ação penal, pode ordenar a produção antecipada de provas consideradas urgentes e relevantes, observando, para tanto, a necessidade, adequação e proporcionalidade da medida".

Cumpre analisar esta relevante alteração legislativa ao lume da Constituição e do garantismo, tendo em vista que tal norma possibilitou ao magistrado a adoção de posição inquisitiva, desempenhando este, pois, um papel investigativo inquisidor (WOTTRICH, 2010, p.128).

Considerando o sistema adotado no Brasil, conquanto a existência das contradições anteriormente debatidas ${ }^{2}$, a desconcentração de funções que o fundamentam e a gestão das provas incumbida às partes (acusador e réu), as quais são cabíveis o ônus da prova e a possibilidade de produzir provas "voluntariamente,

${ }^{2}$ Vide capítulo 1. 
parece difícil conceber a figura de um juiz imparcial e, ao mesmo tempo, responsável pela gestão da prova, ainda que de forma supletiva" (BRESSAN, 2009, p. 90). Logo, a gestão da prova concentrada na figura do julgador fatalmente remonta a uma essência inquisitorial incompatível com a Constituição brasileira (COSTA, 2011, p.111/112).

Quando atribuídos poderes investigatórios ao magistrado, considerando que a gestão/iniciativa probatória é própria do princípio inquisitivo, conduz-se a uma figura de juiz ator e não mero espectador, aniquilando a estrutura dialética do processo penal, o contraditório, o tratamento igualitário e, por fim, a imparcialidade, considerada o princípio supremo do processo (LOPES JR, 2015, p.129).

Veja-se que o inciso I, do artigo 156, do Código de Processo Penal, permite a instauração de outro procedimento, não previsto no ordenamento jurídico, haja vista a possibilidade de persecução probatória antes do estabelecimento da relação processual, o que, manifestamente, remonta à figura de um juiz inquisidor. Destarte, compactuar com essa previsão legal denota aquiescência em relação ao enfraquecimento do sistema acusatório e, consequentemente, à ordem constitucional.

O método acusatório de processo penal considerado mais vetusto, tradicional e dominante, que influencia diversas organizações do sistema de justiça criminal, é o anglo-saxão. Esta metodologia arrosta o juiz como figura passiva e neutra, no que diz respeito à busca das provas, atividade a ser desempenhada exclusivamente pelas partes (PRADO, 2014, p.48).

Em contrapartida, há autores ${ }^{3}$ que entendem ser a previsão dos poderes instrutórios do juiz, alocados no artigo 156 do Código de Processo Penal, consonante com o devido processo legal. Para Francisco Valdez Pereira (2014), a iniciativa instrutória do juiz poderia servir como importante possibilidade de complementação da instrução processual, preenchendo possíveis lacunas advindas do esforço probante das partes, além de entender que a complementação probatória

\footnotetext{
${ }^{3}$ Também defendem a iniciativa probatória ex officio do magistrado no processo penal Guilherme de Souza Nucci, José Carlos Barbosa Moreira, Ivan Luis Marques da Silva, dentre outros.
} 
ex officio é expressa como mecanismo auxiliador do exercício escorreito da própria função jurisdicional.

Do mesmo modo, Silva (2008, p.65-66) defende o argumento de que o trabalho de um magistrado no âmbito criminal, no que tange ao campo das provas, que embasarão a decisão, seja ela pela absolvição ou condenação do imputado, não poderia limitar-se ao de mero espectador. Assim, o juiz não poderia balizar-se apenas à formação de provas pelas partes. Nesse caso, não haveria como se confundir um juiz inquisidor com um magistrado que está cumprindo sua função, devendo buscar consolidar sua decisão assente no máximo de verdade alcançável.

Igualmente, Gomes Filho (MOURA, 2009, p. 259) aponta ser inconcebível que um juiz adote posição totalmente passiva ante a atividade probatória das partes, considerando, ainda, as desigualdades sociais que refletem na seara criminal. Reconhecendo o princípio da imparcialidade como pressuposto da atuação judicial, Gomes Filho entende que a iniciativa probatória do juiz legitima-se se tiver como escopo o esclarecimento completo e rigoroso dos fatos, sem se orientar por predisposição intelectual a um resultado.

Os autores que se mostram favoráveis à possibilidade da iniciativa probatória do juiz entendem que tal previsão, na verdade, auxiliará a persecução da "verdade real", permitindo atitude mais ativa do julgador na busca da elucidação dos fatos, sem que tal posição exprima-se como ofensa ao sistema acusatório.

O inciso I do 156 do Código de Processo Penal previu que o juiz pode determinar a antecipação de provas ex officio antes mesmo de haver-se iniciado a ação penal, logo, anterior à veiculação de uma acusação formal (MENDONÇA, 2008, p.82). Tal previsão viola o devido processo legal, abrindo margem para uma sequência de ofensas aos direitos e garantias fundamentais.

A aplicação do inciso I do art. 156 do Código de Processo Penal contrapõese a um processo penal garantista, no qual - isto é cediço - o magistrado assume verdadeira função de garantidor. $O$ fundamento da legitimidade da jurisdição e da independência do Poder Judiciário está no reconhecimento da sua função de garante dos direitos fundamentais inseridos ou resultantes da Constituição. Neste 
sentido, o juiz atua como verdadeiro protetor dos direitos do acusado no processo penal.

Ibañez (2006, p.33) explica que o exercício da jurisdição revela-se pela imparcialidade, e refere-se a um conjunto de coisas que se mostra ao magistrado como um problema a ser solucionado por ele. Assim, a atividade jurisdicional funciona como um instrumento legal de averiguação do ocorrido a ser resolvido conforme o Direito, notadamente da análise probatória.

Ao analisar-se o teor do artigo 156 do Código de Processo Penal ${ }^{4}$, ainda se considerando que a possibilidade probatória ex officio apenas se instalaria em situações de urgência ou dúvida, argumento este utilizado por aqueles que entendem que tal dispositivo auxilia na busca pela "verdade real" sem caracterizar ofensa ao princípio acusatório ${ }^{5}$, é de reconhecer-se que, mesmo em casos de urgência, a iniciativa probatória deveria ser impulsionada pelo Ministério Público ou, ainda, pelo querelante, como partícipes do processo.

Do mesmo modo, na dúvida, pela máxima in dubio pro reo, e pelo princípio da presunção do estado de inocência, não haveria que se falar em produção de provas, sendo patente a absolvição; a existência de dúvida impõe ao juízo a presunção de inocência (CRUZ, 2013). Assim, tem-se que o princípio da imparcialidade é imprescindível à implementação de um modelo moderno de processo penal garantista.

A imparcialidade do juiz, o devido processo legal e a presunção do estado de inocência constituem premissas constitucionalmente garantidas, estando estas diretamente relacionadas à realização de um Estado Democrático de Direito, não se

\footnotetext{
${ }^{4}$ Art. 156. A prova da alegação incumbirá a quem a fizer, sendo, porém, facultado ao juiz de ofício: (Redação dada pela Lei no 11.690, de 2008) I - ordenar, mesmo antes de iniciada a ação penal, a produção antecipada de provas consideradas urgentes e relevantes, observando a necessidade, adequação e proporcionalidade da medida; II - determinar, no curso da instrução, ou antes de proferir sentença, a realização de diligências para dirimir dúvida sobre ponto relevante. (Incluído pela Lei no 11.690, de 2008).

${ }^{5}$ Nesse sentido, BRASIL. STF, HC 121689 DF. Min. Rel. Luiz Fux. Data de Julgamento 27 de marco de 2014; STJ, RHC 87764 DF Min. Rel. Sebastião Reis Júnior. Data do Julgamento 03 de outubro de 2017.
} 
podendo conceber a flexibilização das garantias constitucionais por previsão infraconstitucional flagrantemente contrária à Constituição.

Tramita nas casas legislativas o Projeto do Novo Código de Processo Penal, no qual foi proposta alteração, via emenda, do artigo $4^{\circ}$. que, além de apontar expressamente o sistema processual adotado, prevê a proibição expressa à iniciativa probatória do magistrado, visto que, ao legitimar essa possibilidade, tal qual acontece atualmente, a teor do artigo 156, I do Código de Processo Penal, estaria sendo adotada a figura de um "juiz defensor", típica efígie do sistema inquisitivo, alcançando um julgador tendencioso e parcial. ${ }^{6}$

Além disso, o caput do artigo 165 do referido Projeto prevê, literalmente, que a produção probatória seja de incumbência das partes, facultando ao juiz, antes de proferir decisão definitiva, a possibilidade de determinar-se diligências com vistas a dirimir eventuais dúvidas sobre a prova produzida pelas partes, previsão esta disposta no parágrafo único do artigo mencionado ${ }^{7}$. Assim, tem-se mais uma proposição do Projeto de Novo Código de Processo Penal (PL ํ․ 8.045/2010) na Câmara dos Deputados, buscando compatibilizar a legislação processual com a Constituição e o sistema acusatório.

Outrossim, tais previsões legais coadunam-se com a lição de Taruffo (2012, p. 224), pela qual o ato decisório emitido pelo magistrado visa a apurar a verdade dos fatos, pressupondo, portanto, um procedimento racional, delimitado por via de regras e princípios passíveis de controle, distanciando-se de julgamentos parciais.

Entende-se por imparcialidade, justiça, equidade e retidão o que implica a separação institucional do juiz em relação às partes, afastando-o da gestão probatória, evitando, ao máximo, o terreno de discricionariedade. O fundamento de sua legitimidade repousa na intangibilidade dos direitos fundamentais, estrutura da democracia substancial.

\footnotetext{
${ }^{6}$ Comitê de análise do projeto do novo CPP. Comissão de acompanhamento legislativo e prerrogativas institucionais. CNPG. ANÁLISE do PROJETO DE LEI 156/2009do Senado (PL 8045/2010 na Câmara), que institui o Novo CÓDIGO DE PROCESSO PENAL. 20 de jul. 2011. p. 13. ${ }^{7}$ Art. 165. As provas serão propostas pelas partes. Parágrafo único. Será facultado ao juiz, antes de proferir a sentença, determinar diligências para esclarecer dúvida sobre a prova produzida por qualquer das partes.
} 
Mediante uma leitura detida sobre a ordem constitucional, constata-se que nesta encontra-se inserido todo o sistema de garantias, em plena sintonia com o garantismo moderno. Neste âmbito, figura a imparcialidade do magistrado, que guarda estreita relação com o princípio da presunção de inocência e o princípio da proibição do non liquet, este último decorrente da indeclinabilidade da prestação jurisdicional.

\section{PRINCÍPIO DA IMPARCIALIDADE CONTRAPOSTO À PRODUÇÃO DE PROVA EX OFFICIO}

Passados o debate quanto aos sistemas processuais penais à luz do constitucionalismo garantista e a explanação acerca da iniciativa probatória do juiz na fase pré-processual, prevista na redação do inciso I do artigo 156 do Código de Processo Penal, importa realizar uma análise mais acurada a respeito da garantia constitucional da imparcialidade e seus reflexos na previsão da produção de prova ex officio no ordenamento jurídico.

Considerando a consagração do sistema acusatório pela Constituição, no qual se atribuem a distintos órgãos as funções de acusar e julgar, não se pode conceber a usurpação do atributo de investigar pelo juiz, sem que haja a considerar que haverá confronto direto desta possibilidade com os direitos e garantias fundamentais previstos na Constituição, sob pena de negar a eficácia destes e, quanto a isto, ensina Streck (2017, p. 557) que "[...] não existe norma constitucional sem perspectiva de eficácia."

O sistema processual adotado contém a desconcentração das atribuições de investigar e julgar para, na tentativa de preservar, notadamente, o princípio da imparcialidade e, em consequência, ratificar o corolário indissociável do acesso à justiça e do devido processo legal.

O postulado da imparcialidade judicial é determinante para entender-se que, ao desempenhar função ativa na persecução criminal, poderia o magistrado 
desequilibrar a disputa processual por imiscuir-se na função do órgão acusatório, ao tempo que passará a constituir em seu íntimo elementos de conviç̧ão, considerando contato antecipado com a fase investigatória.

A equidistância esperada do juiz, condição sine qua non para efetivação da imparcialidade, devendo aquele funcionar como dirigente processual, logo terceiro imparcial naquela contenda, não se coaduna com uma posição ativa ante a persecução criminal, de sorte que o magistrado produzirá provas de fatos que, inevitavelmente, julgará, não mais isento de contaminações e prejulgamentos. Tal contaminação pode ocorrer, até mesmo, de maneira inconsciente considerando que os juízes usam atos de investigação para apoiar suas decisões (COSTA, 2011, p.46).

Taruffo (2012, p.143) leciona sobre a busca da verdade no processo, doutrinando sobre a verdade e a imparcialidade, considerando esta última como princípio fundamental de qualquer sistema de administração de justiça. Importante é mencionar, também, que a garantia da imparcialidade do magistrado não configura algo moral, mas normativo, conforme se denota do próprio sistema jurídico pátrio.

A garantia da imparcialidade mostra-se ainda mais sensível quando se está diante do processo penal, levando-se em conta o fato de que este lida com bens jurídicos valiosos, tais como direito à vida e à liberdade. Assim, a função de julgar querelas criminais exprime-se ainda mais sensível, exigindo do magistrado o dever árduo de distanciar-se de influências provenientes das partes de um litígio.

O Tribunal Europeu de Direitos Humanos (TEDH) considerou contrário ao princípio da imparcialidade do juiz o fato de o magistrado exercer ambas as funções, investigação e persecução, ou seja, se o juiz lançou mão de seu poder investigatório na fase pré-processual, não poderá, no curso processual, ser o julgador, o que seria uma violação do direito ao juiz imparcial consagrado no art. 
6.1 do Convênio para a Proteção dos Direitos Humanos e das Liberdades Fundamentais, de $1950^{8}$.

Ademais, não se pode confundir neutralidade com imparcialidade no desempenho da função julgadora. A neutralidade permeia a seara da valoração, das crenças e outras características ideológicas que possam vir a influenciar a ciência do julgamento. O juiz, na qualidade de ser humano, traz ínsitas perspectivas e convicções advindas de suas vivências, o que, contudo, não macula o agir com imparcialidade, pois não necessariamente a abstenção da neutralidade ultraja a imparcialidade (DUARTE, 2014).

As atividades postulatórias e instrutórias das partes litigantes irão compor a formação do convencimento do magistrado, enquanto este, imbuído do dever de zelar pela lisura do julgamento e pela realização da justiça, deve lançar análises desnudas de prejulgamentos. De efeito, denota-se a garantia da imparcialidade como contraposição à possibilidade de produção de prova ex officio pelo magistrado.

A atribuição de buscar provas é das instituições repressivas e do Ministério Público. Destarte, o magistrado deve manter-se distante da tarefa de investigar o fato, considerando, ainda, que o Ministério Público é o titular da ação criminal, sob pena de comprometer-se a imparcialidade do julgador (VALE, 2017, p.143). Assim, resta claro o conflito entre a previsão infraconstitucional de iniciativa probatória ex officio, pelo juiz, e a garantia da imparcialidade prevista na Constituição.

\section{CONSIDERAÇÕES FINAIS}

Analisou-se o teor do inciso I do artigo 156 do Código de Processo Penal, prevendo a possibilidade de iniciativa probatória de ofício pelo juiz, pela qual se verificou que tal norma exprime-se como resquício de um regime inquisitorial, haja

\footnotetext{
${ }^{8}$ Sentencia del Tribunal Europeo de Derechos Humanos de Estrasburgo. Caso Piersack contra Bélgica (Demanda ํ‥ 8692/1979).
} 
vista que afronta a direitos e garantias fundamentais, notadamente o princípio da imparcialidade, alcançada por meio do distanciamento do magistrado da função probatória.

O sistema acusatório, característica do Estado Democrático de Direito, tendo como função a proteção e a promoção dos direitos e garantias fundamentais, quando tem alcance de atribuir poderes instrutórios ao julgador, manifesta-se conflitante com o princípio da imparcialidade, motivo pelo qual é objeto de patente inconstitucionalidade.

A adoção do sistema acusatório pela própria Constituição tende a afastar as normas que remontem à figura de um juiz inquisidor, devendo este ater-se às atribuições estabelecidas de maneira minuciosa, pelo Texto Constitucional, que segregou as funções investigatórias e jurisdicionais, não competindo ao magistrado a tarefa de investigar e produzir provas, sob pena de afronta ao sistema acusatório.

A iniciativa probatória pelo juiz na fase pré-processual nos termos do inciso I do art. 156 do Código de Processo Penal, dispositivo claramente influenciado pelo sistema inquisitivo, sendo este norteador do Código de Processo Penal italiano de 1930, absolutamente fascista, afronta os mais elementares princípios que integram o modelo garantista do processo penal, necessariamente acusatório, adotado pela Constituição, notadamente os princípios da imparcialidade e do devido processo legal.

\section{REFERÊNCIAS}

BARROS, Marco Antônio de. A busca da verdade no processo penal. 3. ed. São Paulo: Revista dos Tribunais, 2012

BRASIL. Decreto Lei o․ 3.689, de 3 de outubro de 1941. Código de Processo Penal. Brasília, DF. Disponível em: <http://www.planalto.gov.br/ccivil_03/decretolei/Del3689.htm>. Acesso em: 16 set. 2018.

. Lei no. 9.034, de 25 de julho de 2000. Dispõe sobre a utilização de meios operacionais para a prevenção e repressão de ações praticadas por organizações 
criminosas. Brasília, DF. Disponível em: <http://www.planalto.gov.br/ccivil_03/leis//9034.htm>. Acesso em: 29 out. 2018.

BRESSAN, Walter Eduardo Maranhão. A admissibilidade de gestão da prova por juiz imparcial no sistema processual penal acusatório e o artigo 156, inciso I, do Código de Processo Penal, em face da Constituição Federal. Revista de Direito UPIS. Brasília, 2009.

CABRAL, Flávio Garcia. A imparcialidade objetiva do juiz. Revista Jus Navigandi, ISSN 1518-4862, Teresina, ano 14, n. 2374, 31 dez. 2009. Disponível em: <https://jus.com.br/artigos/14111>. Acesso em: 30 out. 2018.

COMITÊ DE ANÁLISE DO PROJETO DO NOVO CPP. Comissão de acompanhamento legislativo e prerrogativas institucionais. Conselho Nacional de Procuradores Gerais de Justiça CNPG. ANÁLISE do PROJETO DE LEI 156/2009 do Senado (PL 8045/2010 na Câmara), que institui o Novo CÓDIGO DE PROCESSO PENAL. 20 de jul. 2011. Disponível em: $<$ http://paginasdeprocessopenal.com.br/wp-content/uploads/2015/02/cpp-reformamj.pdf>. Acesso em: 29 de out. 2018.

COSTA, Cristine Osternack. A contaminação (in)consciente do julgador pela investigação criminal. Revista Jurídica UNICURITIBA, ISSN: 2316-753X, Curitiba, v. $27, \quad$ n. $11, \quad$ p. $37-69, \quad$ (2011.2). Disponível em: $<$ http://revista.unicuritiba.edu.br/index.php/RevJur/issue/view/40>. Acesso em: 20 set. 2019.

A investigação criminal no Brasil e em Portugal: reflexões sobre a figura do promotor investigador. Revista Jurídica UNICURITIBA, ISSN: 2316-753X, Curitiba, v. 26, n. 10, p. 99-148, (2011). Disponível em: <http://revista.unicuritiba.edu.br/index.php/RevJur/issue/view/33>. Acesso em: 20 set. 2019.

CRUZ, Clenderson Rodrigues da.A (in)constitucionalidade dos poderes instrutórios do juízo penal frente ao estado democrático de direito. Boletim Jurídico, Uberaba/MG, a. 13, no 1128 . Disponível em: $<$ https://www.boletimjuridico.com.br/doutrina/artigo/3142/a-in-constitucionalidadepoderes-instrutorios-juizo-penal-frente-ao-estado-democratico-direito>. Acesso em: 24 out. 2018.

DUARTE, Hugo Garcez.; BARBOSA. Jadson de Oliveira. Neutralidade e Imparcialidade: análise frente a função judicante no constitucionalismo contemporâneo. Prisma Jurídico, São Paulo, v. 13, n. 2, pp. 9-35, jan/jun. 2014. Disponível em: $<$ https://periodicos.uninove.br/index.php?journal=prisma\&page=article\&op=view\&pat h\%5B\%5D=3971>. Acesso em: 27 ago. 2019. 
FERRAJOLI, Luigi. Direito e razão: teoria do garantismo penal. São Paulo: Revista dos Tribunais, 2002.

Trotta, 2001.

Los fundamentos de los derechos fundamentales. Madrid: Editorial

FISCHER, Douglas. O sistema acusatório brasileiro à luz da constituição federal de 1988 e o PL 156. Custus Legis Revista eletrônica do Ministério Público Federal, 2011.

IBÁÑEZ, Perfecto Andrés. Valoração da prova e sentença penal. Organização e prefácio Lédio Rosa de Andrade. Rio de Janeiro: Lumen Juris, 2006.

IPPOLITO, Dario. O garantismo de Luigi Ferrajoli. Tradução por Hermes Zaneti Junior. Revista de Estudos Constitucionais, Hermenêutica e Teoria do Direito (RECHTD), Roma. 3(1): 34-41. jan. / jun. 2011.

LIMA, Leonardo Biagioni de. Uma leitura epistemológica do processo penal garantista. Revista eletrônica da Faculdade de Direito de Franca, v. 6, n.1, dez. 2012.

$<$ https://www.revista.direitofranca.br/index.php/refdf/article/view/198/125>. Acesso em 22 set. 2018.

LOPES JUNIOR, Aury. Sistemas de Investigação Preliminar no Processo Penal. 3. Ed. Rio de Janeiro: Lumen luris, 2005.

. Direito processual penal e sua conformidade constitucional. Vol. I. Rio de Janeiro: Lumen Juris, 2007.

Direito processual penal e sua conformidade constitucional. Vol. II. 3. Ed. Rio de Janeiro: Lumen Juris, 2010.

MENDONÇA, Andrey Borges de. Os elementos produzidos durante o inquérito e a provas antecipadas, cautelares e irrepetíveis, segundo a reforma do CPP. Revista da Escola Superior do Ministério Público de São Paulo. Ano 1, n 1, vol. 2, pp. 7587. Disponível em: <http://www.esmp.sp.gov.br/2010/revista1_vol2_2008.pdf>. Acesso em 10 out. 2018.

MINÁ, Frederico Ivens, CEREJO, Saulo Baqueiro. Da impossibilidade da autoridade judiciária determinar provas ex-officio - Art. 156 do CPP. Disponível

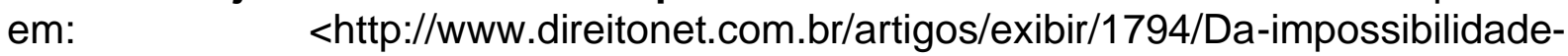
daautoridade- judiciaria-determinar-provas-ex-officio-Art-156-do-CPP>. Acesso em 10 out. de 2018.

MIRANDA, Jorge. Estado social e direitos fundamentais. DOUTRINA: Superior Tribunal de Justiça: edição comemorativa 15 anos. Brasília, DF, 2005. p. 199- 
219.

$<$ https://ww2.stj.jus.br/publicacaoinstitucional///index.php/Dout15anos/issue/archive> . Acesso em: 24 set. 2019.

MOURA, Maria Thereza Rocha de Assis, coord. As reformas no processo penal: As novas Leis de 2008 e os Projetos de Reforma. São Paulo: Revista dos Tribunais, 2009.

PEREIRA, Frederico Valdez. Iniciativa Probatória de Ofício e o Direito ao Juiz Imparcial no Processo Penal. Porto Alegre: Livraria do Advogado, 2014.

PIMENTEL, Vanessa Miceli de Oliveira. Constitucionalismo e garantismo: sistema jurídico-penal antigarantista e o constitucionalismo brasileiro tardio. Âmbito Jurídico. Disponível em: <http://www.ambitojuridico.com.br/site/?n_link=revista_artigos_leitura\&artigo_id=18656\&revista_cadern $0=3>$. Acesso em 10 out. 2018.

PRADO, Geraldo. Prova penal e sistema de controles epistêmicos: a quebra da cadeira de custódia das provas obtidas por métodos ocultos. São Paulo: Marcial Pons, 2014.

O Sistema Acusatório: A conformidade Constitucional das Leis Processuais Penais.3. ed.Rio de Janeiro: Editora Lumen Juris, 2005.

RIBEIRO, Pedro Melo Pouchain. O sistema acusatório e a iniciativa probatória do juiz (art. 156, inciso I, CPP). Disponível em: <https://jus.com.br/artigos/21526/osistema-acusatorio-e-a-iniciativa-probatoria-do-juiz-art-156-inciso-i-cpp>. Acesso em 10 out. 2018.

ROSA, Alexandre Morais da. O que é garantismo jurídico (Teoria Geral do Direito). Florianópolis: Habitus, 2003.

SABOIA, Jessica Ramos. SANTIAGO, Nestor Eduardo Araruna. Garantismo e ativismo judicial: uma análise da presunção do estado de inocência e da sua relativização pelo STF.Revista Direitos Fundamentais \& Democracia.v. 23, n. 2, mai./ago. 2018

. Garantismo e sistema acusatório no processo penal democrático brasileiro: os discursos acerca da acusatoriedade no Superior Tribunal de Justiça e no Supremo Tribunal Federal, a partir da Teorização Fundamentada nos Dados. 2018. (Dissertação Mestrado em Direito Constitucional). Universidade de Fortaleza. Fortaleza, Ceará.

SARLET, Ingo Wolfgang. A eficácia dos direitos fundamentais. 12. ed. Porto Alegre: Livraria dos Advogados, 2015. 
SENTENCIA DEL TRIBUNAL EUROPEO DE DERECHOS HUMANOS DE ESTRASBURGO. CASO PIERSACK CONTRA BÉLGICA (Demanda núm. 8692/1979) Disponível em: <http://www.cienciaspenales.net/files/2016/10/6casopiersack-contra-belgica-derecho-a-un-proceso-independiente-e-imparcial.pdf>. Acesso em: 30 out. 2018.

SILVA, Ana Paula Pinto da; SANTIAGO, Nestor Eduardo Araruna. Defesa efetiva, garantismo e eficiência no processo penal: o que o Supremo Tribunal Federal tem a ver com isso?Direito Público. Porto Alegre, ano 8, n. 40, pp.50-73, jul./ago. 2011.

SILVA, Ivan Luís Marques. Reforma Processual Penal de 2008. São Paulo: Revista dos Tribunais, 2008.

SILVA, Pollyanna Maria da; FRANCISCO, Francislaine Rosa Chagas. MENDES, Michael Araújo. A (in)constitucionalidade do art. 156 do cpp face aos princípios da presunção da inocência e do devido processo legal. Revista de Iniciação Científica. Disponível em: <https://www.univali.br/graduacao/direitoitajai/publicacoes/revista-de-iniciacao-cientificaricc/edicoes/Lists/Artigos/Attachments/703/016.pdf>. Acesso em: 05 out. 2018.

SOUZA, Luiz Roberto Salles; CARBONI, Christian Marcos. A reafirmação do processo acusatório e contraditório no processo penal brasileiro: as reformas de junho de 2008. Revista da Escola Superior do Ministério Público de São Paulo. Ano 1, n 1, vol. 2, pp. 41-46. Julho/dezembro 2008. Disponível em: <http://www.esmp.sp.gov.br/2010/revista1_vol2_2008.pdf>. Acesso em: 10 out. 2018.

STF, HABEAS CORPUS: HC o 95.009/SP. Relator: Ministro Eros Grau. Dje 18/12/2008. Disponível em: <

http://combodia.ohchr.org/sites/default/files/echrsource/Piersack\%20v\%20Belgiu\%20 [1\%200ct\%201982]. Pdf. Acesso em: 30 de out.2018.

STJ.HABEAS CORPUS: HC 114478-pr-2008-0191220-0-stj. Relator: Ministro Rogerio Schietti Cruz. Dje 25/04/2014. JusBrasil, 2014. Disponível em: $<$ https://stj.jusbrasil.com.br/jurisprudencia/25053008/habeas-corpus-hc-114478-pr2008-0191220-0-stj/inteiro-teor-25053009 >. Acesso em: 29 de out. 2018

STJ. HABEAS CORPUS: HC 114478-pr-2008-0191220-0-stj. Relator: Ministro Nilson Naves. Dje 18/05/2010. JusBrasil, 2010. Disponível em: $<$ https://stj.jusbrasil.com.br/jurisprudencia/14663686/habeas-corpus-hc-143889-sp2009-0150059-3/inteiro-teor-14663687 >. Acesso em: 28 de out. 2018.

STRECK, Lênio Luiz. Verdade e consenso. 6. ed. São Paulo: Saraiva, 2017.

TARUFFO, Michele. Uma simples verdade. O juiz e a construção dos fatos. Tradução Vitor de Paula Ramos, São Paulo: Marcial Pons, 2012. 
VALE, Ionilton Pereira do; SANTOS, Teodoro Silva. O princípio nemo tenetur se ipsum accursare ou o direito à não autoinculpação e os aspectos relacionados ao direito ao silêncio no processo penal brasileiro. Rio de Janeiro: Lumen Juris, 2017.

WOTTRICH, Lisandro Luís. O sistema inquisitorial: o inciso I do artigo 156 do Código de Processo Penal e a produção antecipada de provas. Revista Jurídica 392 (Doutrina Penal), p.123-136. Jun. 2010. Disponível em: <http://www.bdr.sintese.com/AnexosPDF/RJ\%20392\%20\%20Doutrina\%20Penal.pdf>. Acesso em: 17 out. 2018. 